\title{
Intimate relationship quality, self-concept and illness acceptance in those with multiple sclerosis
}

Thomas M. Wright and Litza A. Kiropoulos

Melbourne School of Psychological Sciences, University of Melbourne, Melbourne, Victoria, Australia 3010

Corresponding author: Thomas M. Wright, wright.t@unimelb.edu.au

This research received no specific grant from any funding agency in the public, commercial or not-for-profit sectors. We would like to acknowledge MS Australia, Multiple Sclerosis Research Australia, Kiss Goodbye to MS, Overcoming Multiple Sclerosis, CCSVI Australia, Shift MS, and Multiple Sclerosis Foundation for their assistance in advertising the present study and the participants for taking part in the study. 


\section{Intimate relationship quality, self-concept and illness acceptance in those with multiple sclerosis}

Lower levels of Intimate Relationship Quality (IRQ) have been found in those with Multiple Sclerosis (MS) compared to the general population. This study examined an MS sample to see whether IRQ was positively associated with self-concept, whether IRQ was positively associated with MS illness acceptance and whether IRQ was predicted by self-concept and illness acceptance. In this cross-sectional study, 115 participants with MS who were in an intimate relationship completed an online survey advertised on MS related websites. The survey assessed demographic variables, MS illness variables and levels of IRQ, self-concept and illness acceptance. Results revealed that IRQ was significantly positively associated with self-concept and with illness acceptance. Multiple hierarchical linear regression analysis revealed that, after controlling for illness duration and level of disability, self-concept significantly predicted IRQ but illness acceptance did not significantly predict IRQ. This study addressed several gaps and methodological flaws in the literature and was the first known to assess predictors of IRQ in those with MS. The results suggest that selfconcept could be a potential target for individual and couple psychological interventions to improve IRQ and contribute to improved outcomes for those with MS.

Keywords: Intimate relationship quality, self-concept, illness acceptance, multiple sclerosis

\section{Introduction}

Multiple Sclerosis (MS) is a chronic, degenerative disorder involving problems transmitting nerve impulses throughout the brain and spinal cord, resulting in wide ranging physical and neurological impairments (Feinstein, 2007). The aetiology of MS is still unknown, the course of illness is unpredictable and at present there is no cure (Rao, Huber, \& Bornstein, 1992). 
Adjustment to MS involves positively assimilating the changes into one’s life, continued psychosocial development and maintaining a positive life outlook (Antonak \& Livneh, 1995; Marks \& Miller, 1990). A better understanding about adjustment factors may contribute to improved outcomes for individuals with MS.

Intimate Relationship Quality (IRQ) is yet to be fully explored in those with MS. An intimate relationship involves two individuals predictably interacting with each other emotionally and physically, regardless of legal marital status (Prager, 1995, p. 23). High IRQ typically encompasses effective communication, problem solving, support, satisfaction and expressions of sensuality/sexuality while low IRQ may involve deficits in several of these areas (Ahlborg, Lilleengen, Lönnfjord, \& Petersen, 2009; Baucom, Epstein \& La Tillade, 2002).

Low IRQ has been associated with poorer mental and physical health in MS and other chronic illness populations (Coyne, Rohrbaugh, Shoham, Sonnega, \& Nicklas, 2001; McPheters \& Sandberg, 2010). Studies have shown lower relationship satisfaction and higher risk of relationship termination in those with MS compared to healthy controls (McCabe, 2002; Pfleger, Flachs, \& Koch-Henriksen, 2010). This could be due to feelings of inequity, dependency, stress and caregiver burnout in the intimate relationships of those with MS (McCabe, McDonald, Deeks, Vowels, \& Cobain, 1996; Ybema, Kuijer, Hagedoorn, \& Buunk, 2002).

MS does not always lead to decline in IRQ and can bring couples closer together (Mohr et al., 1999; McCabe, 2004). It is important to explore why this is the case and to identify protective psychological factors associated with improved IRQ, so that these factors can be targeted in future research and psychological interventions. Employing a strengthsbased approach (Saleebey, 2009), this study will examine whether self-concept and MS illness acceptance are protective factors for IRQ in an MS population. 
Self-concept is a possible protective factor for IRQ. Self-concept is an individual's perception of their identity, adjustment, social skills and status, self-fulfilment, physicality and morality (Fitts \& Warren, 1996). Self-concept and associated self-esteem has been found to be consistently low in MS populations (McCabe, 2005), consistent with the negotiation model of self and illness proposing that chronic illness inevitably results in a loss of self (Gerhardt, 1989). Other studies, however, show that MS can have positive effects relating to increased self-concept (Dutton, Simpson \& Boot, 2012; Brooks \& Matson, 2012).

The association between self-concept and IRQ has received little research attention. Qualitative research shows that romantic partners are important in dealing with self-concept changes linked with MS (Kralik, Koch \& Eastwood, 2003). Dlugonski and Motl (2012) found that social support is significantly associated with positive self-esteem in those with MS, but did not focus specifically on IRQ. Nosek, Howland, Rintala, Young and Chanpong (2001) found that in women with disabilities, satisfying intimate relationships and having a job were related to high levels of self-esteem, however their study was not specific to MS. Much of the research has used measures examining self-esteem rather than self-concept in those with MS, which are different constructs in terms of domain-specificity (Arens \& Hasselhorn, 2014). A better understanding of the relationship between self-concept and IRQ in those with MS is needed.

Another possible protective factor for IRQ is illness acceptance, which involves coming to terms with the illness course, emotionally internalising implications of impairments and social reintegration (Stuifbergen, Becker, Blozis, Beal, \& Park, 2008). Acceptance of MS is linked with a variety of positive outcomes including improved satisfaction with life (Pakenham, 2007; Pakenham \& Fleming, 2011).

It is, therefore, important to investigate the association between MS acceptance and IRQ. Harrison, Stuifbergen, Adachi, and Becker (2004) found that being married was 
associated with greater disability acceptance. Pakenham and Fleming (2011) found that married participants showed higher MS acceptance than single participants and that higher levels of MS acceptance was associated with better marital adjustment.

Pakenham and Samios’ (2013) results showed that MS acceptance was not associated with self-reported relationship satisfaction, but was associated with partner-reported relationship satisfaction. The study employed non-random sampling of couples with children from one community and the results may not be generalisable. The current study will recruit people from local and international MS-related sites to ensure that a wider range of ages and backgrounds is represented. Given the limited and conflicting literature on the relationship between MS acceptance and IRQ, further research is required.

It is clear that IRQ is an important adjustment factor for those with MS requiring further exploration. Some studies have used measures that only assess marital/relationship satisfaction, neglecting other aspects of IRQ such as consensus, cohesion, sensuality, and sexuality (Ahlborg et al., 2009) or have used very brief measures to assess IRQ. The current study will assess IRQ with an updated and comprehensive scale, the Quality of Dyadic Relationships Scale 36 (Ahlborg et al., 2009). Many studies have focused only on marriage when examining IRQ, failing to include unmarried individuals in committed relationships, which the current study will allow. There have been conflicting results about the presence of associations between IRQ and MS acceptance and there is a lack of research investigating IRQ and self-concept. Very limited information is also available about predictors of IRQ, especially examining self-concept and MS illness acceptance.

The current study will examine IRQ and its relationships with both self-concept and illness acceptance in those with MS. It is hypothesised that IRQ will be positively associated with self-concept and with MS illness acceptance. It is also hypothesised that, after 
controlling for illness duration and levels of disability, IRQ will be predicted by self-concept and by MS illness acceptance.

\section{Methods}

\section{Participants}

Participants volunteered to participate via the electronic online survey link that was published on websites of Multiple Sclerosis Research Australia, Overcoming Multiple Sclerosis, MS Australia, CCSVI Australia, Shift MS, and Multiple Sclerosis Foundation. Individuals were required to have received a confirmed MS diagnosis from a neurologist and be in an intimate relationship to participate. 237 individuals participated in the online survey, however 122 withdrew before survey completion. Seven participants not currently in an intimate relationship were excluded. The final sample consisted of 115 participants with a mean age of $42.20(\mathrm{SD}=10.87$, range $=20-68)$. There were 18 males and 95 females and the majority of participants identified as Australian (45.20\%) and North American/Canadian (21.70\%). The sample consisted of predominantly married individuals (72.2\%). The majority of participants were employed either full-time (40\%) or part-time/casually (22.6\%). Most participants had attained further education qualifications after finishing secondary school (88.2\%). 87\% of participants were diagnosed with relapse-remitting MS and 10.4\% diagnosed with progressive MS, with 2.6\% not answering this question. The mean MS illness duration was 7.81 years $(\mathrm{SD}=8.09)$ and $71.3 \%$ were currently taking medication to treat their MS symptoms. The majority of participants (76.5\%) did not need assistance when walking.

\section{Procedures}

The current study was cross-sectional. An online survey was created using the Qualtrics website and the survey link was posted on MS-related websites, which presented participants 
with a plain language statement and consent from. Participants provided consent by selecting the 'Yes, I agree' option and providing email addresses. Participants were allowed one week to complete the survey and were able to withdraw their participation at any time by exiting the survey. The University of Melbourne Behavioural and Social Sciences Human Ethics Committee granted ethics approval for this study.

\section{Measures}

Participants provided information on age, gender, education history, relationship status, employment status and ethnic background. Participants provided data on the number of years and months since diagnosis, first MS symptoms experienced, history of symptom relapse and MS sub-type. The 'Walking Distances’ scale of the Expanded Disability Status Scale (EDSS) (Bowen, Gibbons, Gianas \& Kraft, 2001) was completed to assess degree of mobility impairment, which has previously been used with MS populations (Cao et al., 2013).

The 36-item Quality of Dyadic Relationships Scale (QDR36) was used to measure IRQ. It is a rating-scale questionnaire assessing 5 aspects of relationship quality: dyadic consensus, cohesion, satisfaction, sensuality, and sexuality (Ahlborg et al., 2009). Responses are on rating scales ranging from (1) to (6) with negatively worded items reverse scored. A score for each aspect of relationship quality and an overall score can be attained. QRD36 is an updated extended version of the widely used Dyadic Adjustment Scale (Spanier, 1976). Higher overall scores indicate greater relationship quality. The overall $\alpha$ reliability coefficient in the current study was 0.94. The QDR36 has not been used with an MS sample but has been used with a chronic pain sample (Edlund et al., 2015).

The Tennessee Self-Concept Scale (TSCS-2) was used to measure self-concept. It is an 82-item questionnaire producing two summary scores (Total Self-Concept, Conflict), six self-concept scores (Physical, Moral, Personal, Family, Social, Academic/Work), and three 
supplementary scores (Identity, Satisfaction, Behaviour) (Fitts \& Warren, 1996). Responses are on a five-point scale ranging from always false (1) to always true (5) with negatively worded items reverse scored. The total self-concept score combines the six self-concept scores. Higher scores indicate more positive self-concept, but high scores above 70 may indicate inflated self-concept, defensive attitude or distress. In the current study, participants completed all 82 items but only the overall self-concept scores were further analysed, which had $\alpha$ reliability coefficient of 0.90 .

The 10-item Acceptance of Chronic Health Conditions Scale (ACHC), adapted for an MS population, was used to measure MS illness acceptance (Stuifbergen, Becker, Clozis, Beal \& Park, 2008). Items are scored on a five point scale ranging from strongly agree (1) to strongly disagree (5) with reverse scoring for positively phrased questions. Higher overall scores indicate greater levels of acceptance of MS illness. The $\alpha$ reliability coefficient for the scale in the current study was 0.81 .

\section{Statistical Analyses}

In Statistical Package of Social Science Version 22, Spearman correlations were used to examine the associations between IRQ, self-concept and MS illness acceptance. Multiple hierarchical linear regression analyses were used to examine whether self-concept and MS illness acceptance were significant predictors of IRQ.

\section{Results}

\section{Missing data analysis}

For the 115 participants, missing values analyses revealed minimal missing data. Little’s (1998) test indicated that the missing data was missing at random and ignorable, $\chi^{2}(5227)=$ $609.64, p=1.00$. For the TSCS-2, if more than eight replacements were required for overall 
self-concept score then scoring did not proceed for that participant on that measure. If more than $20 \%$ of responses were missing on the QDR36 or ACHC then scoring did not continue for those participants on those measures. Missing values on all measures were estimated using the expectation maximisation technique.

\section{Univariate analyses}

For each measure the means, standard deviations, range, and number of participants completing the measure are reported in Table 1. To examine whether IRQ was positively associated with self-concept and with MS illness acceptance, correlational analyses between the psychological variables of interest were conducted and the results are shown in Table 2. Histograms and skewness statistics revealed slight non-normality in the distribution of IRQ, therefore, nonparametric Spearman’s correlation coefficients were used. All correlation coefficients were statistically significant. IRQ was positively associated with self-concept and with MS illness acceptance. No variables were correlated at or above 0.90 , which suggested the data may be suitable for multivariate analysis (Tabachnick \& Fidell, 2007).

\section{Multivariate analyses}

To examine whether self-concept and MS illness acceptance were significant predictors of IRQ, after controlling for illness duration and level of disability, a multiple hierarchical linear regression analysis was conducted. The multiple hierarchical linear regression involved two steps and the results are shown in Table 3 The first step examined whether illness duration and level of disability predicted IRQ. Only level of disability significantly predicted IRQ. The second step involved including self-concept and MS illness acceptance, resulting in the model explaining an extra 19\% of variance in IRQ. The only 
significant predictor was self-concept, indicating that for every unit increase in self-concept there will be a 0.43 standard deviation increase in IRQ.

\section{Discussion}

In the sample of those with MS, we found that IRQ was significantly positively associated with self-concept and significantly positively associated with illness acceptance. We also found that self-concept was a significant predictor of IRQ but that MS illness acceptance was not a significant predictor. While this is the first study directly assessing the relationship between IRQ and self-concept, the positive association found between these variables is consistent with the trend found in the few previous studies indirectly examining these variables (Dlugonski \& Motl, 2012; Kralik et al. 2003; Nosek et al., 2001).

The results showing a significant positive association between IRQ and MS illness acceptance are consistent with research by Pakenham and Fleming (2011) and by Harrison et al., (2004). The results are conflicting with Pakenham and Samios (2013) finding that MS patient illness acceptance was not related to self-reported relationship satisfaction, possibly because they used a different scale to measure only a portion of overall IRQ.

The first step of the multiple logistic regression revealed that level of disability was a significant negative predictor of IRQ, consistent with previous research showing a correlation between disability levels and mental health outcomes (Goksel Karatepe et al., 2011;

Tsivgoulis, 2007). After controlling for illness duration and level of disability, the second step of the logistic regression revealed that self-concept was a significant predictor of IRQ but that MS illness acceptance was not. One explanation for this finding is that those with higher levels of self-concept may have more confidence in their worthiness and ability to initiate and maintain intimate relationships than those with lower levels of self-concept (Nosek, Hughes, Swendlunda, Taylora \& Swank, 2003), which may contribute to more positive experiences and appraisals of their relationships. 
The finding that MS illness acceptance did not predict IRQ is possibly due to the fact that MS illness acceptance may predict IRQ in isolation but not when self-concept is also included, because the two are moderately correlated and may share variance explained in IRQ. Alternatively, the direction may be different with IRQ instead predicting MS illness acceptance, which is a potential avenue for future investigation. Self-concept was the most important predictor of IRQ and was the most strongly correlated variable with IRQ, which suggests that self-concept may be a protective factor against impaired IRQ.

The current study successfully improved on several methodological limitations and research gaps in the literature. It is the first known study to quantitatively examine the relationship between IRQ and self-concept in those with MS and the first known to examine predictive relationships between these variables. The use of the QDR36 scale, a comprehensive and updated measure of IRQ improves upon IRQ measurement in most of the studies in this area. Furthermore, allowing unmarried couples to participate may have more accurately captured a more representative sample of intimate relationships than previous research. The sample included participants from a variety of cultural backgrounds, strengthening the generalisability of the results across different cultural groups, although the majority were from Western cultures.

The current results, however, must be viewed in light of some limitations. The crosssectional nature of the study means the results cannot show whether these relationships are stable over time. Given the long term nature of MS and that the variables of interest are dynamic processes, future research should extend this study by conducting longitudinal research. The majority of participants were female (84\%), and although females are more commonly diagnosed with MS than males (Ghezzi, 2004), there is a large gender imbalance in the current study. 
The majority of the participants in the sample had relatively high and positive levels of IRQ, self-concept and MS illness acceptance, a conflicting profile with previous MS research profiles (McCabe, 2002; McCabe, 2005). This is possibly because the voluntary survey was more likely to appeal to and be completed by those with favourable adjustment profiles. It is also possible that by excluding participants who were currently single, the sample did not capture all of those with MS who have experienced intimate relationship breakdowns and difficulties. Replication of the current findings in other samples with MS is required. An extension of the current study could be to examine the profiles and perceptions of IRQ for both MS patients and their partners, which may differ. The regression model explained $25.5 \%$ of the variance in the IRQ, so there may be other factors outside the scope of this study that more strongly predict IRQ and responses and adjustment issues from the partner may be one such factor impacting patient IRQ and adjustment.

In conclusion, this study has contributed to our understanding of the relationships between IRQ and self-concept and between IRQ and MS illness acceptance. The current results suggest that IRQ is strongly related to both self-concept and MS illness acceptance. Furthermore, self-concept is a significant predictor of IRQ. The results suggest that individual and couple psychological intervention programs and strategies targeting adjustment to MS should focus on nurturing and improving self-concept. This may help to improve IRQ and contribute to a greater quality of life for those suffering from this debilitating illness. 


\section{Acknowledgments}

This research received no specific grant from any funding agency in the public, commercial or not-for-profit sectors. We would like to acknowledge MS Australia, Multiple Sclerosis Research Australia, Kiss Goodbye to MS, Overcoming Multiple Sclerosis, CCSVI Australia, Shift MS, and Multiple Sclerosis Foundation for their assistance in advertising the present study and the participants for taking part in the study. 


\section{References}

Ahlborg, T., Lilleengen, A., Lönnfjord, V., \& Petersen, C. (2009). Quality of dyadic relationship in Swedish men and women living in long-term relationships and in couples in family counselling - Introduction of a new self-report measure, QDR36. Nordic Psychology, 61, 23-46. doi:10.1027/1901-2276.61.3.23

Antonak, R., \& Livneh, H. (1995). Psychosocial adaptation to disability and its investigation among persons with multiple sclerosis. Social Science \& Medical, 40(8), 1099-1108. doi:10.1016/02779536(94)00167-R

Arens, A. K., \& Hasselhorn, M. (2014). Age and Gender Differences in the Relation between Self-Concept Facets and Self-Esteem. Journal Of Early Adolescence, 34(6), 760-791. doi: $10.1177 / 0272431613503216$

Baucom, D. H., Epstein, N., \& La Tillade J. L. (2002). Cognitive- Behavioral Therapy. In A. S. Gurman \& N. S. Jacobson (Eds.), Clinical Handbook of Couple Therapy, (pp. 26 58). New York, NY: The Guilford Press.

Bowen, J., Gibbons, L., Gianas, A., \& Kraft, G. H. (2001). Self-administered Expanded Disability Status Scale with functional system scores correlates well with a physician administered test. Multiple Sclerosis, 7(3), 201-206.

doi:10.1177/135245850100700311

Brooks, N. A., \& Matson, R. R. (1982). Social-psychological adjustment to multiple sclerosis. A longitudinal study. Social Science \& Medicine, 16(24), 2129-2135. 
doi:10.1016/0277-9536(82)90262-3.

Cao, H., Peyrodie, L., Boudet, S., Cavillon, F., Agnani, O., Hautecoeur, P., \& Donzé, C. (2013). Expanded Disability Status Scale (EDSS) estimation in multiple sclerosis from posturographic data. Gait \& Posture, 37(2), 242-245.

doi:10.1016/j.gaitpost.2012.07.011

Coyne, J. C., Rohrbaugh, M. J., Shoham, V., Sonnega, J. S., \& Nicklas, J. M. (2001).

Prognostic importance of marital quality for survival of congestive heart failure.

American Journal of Cardiology, 88, 526-529. doi:10.1016/S0002-9149(01)01731-3

Dlugonski, D., \& Motl, R. W. (2012). Possible Antecedents and Consequences of Self

Esteem in Persons With Multiple Sclerosis: Preliminary Evidence From a Cross

Sectional Analysis. Rehabilitation Psychology, 57(1), 35-42. doi: 10.1037/a0027176

Dutton, L. M., Simpson, J., \& Boot, J. (2012) MS and me: exploring the impact of multiple

sclerosis on perceptions of self. Disability \& Rehabilitation, 34(14), 1208-1217. doi:

$10.3109 / 09638288.2011 .638032$

Edlund, S. M., Carlsson, M. L., Linton, S. J., Fruzzetti, A. E., \& Tillfors, M. (2015). I see you're in pain - The effects of partner validation on emotions in people with chronic pain. Scandinavian Journal of Pain, 6, 16-21. doi:10.1016/j.sjpain.2014.07.003

Feinstein, A. (2007). Multiple sclerosis: diagnosis and definitions. The Clinical Neuropsychiatry of Multiple Sclerosis ( $2^{\text {nd }}$ ed., pp. 1-27). Cambridge: Cambridge University Press. 
Fitts, W. H., \& Warren, W. L. (1996). Tennessee Self-Concept Scale, TSCS: 2. Second Edition, Manual. Los Angeles, CA: Western Psychological Services.

Gerhardt, U. (1989). Ideas about illness: an intellectual and political history of medical sociology. New York: New York University Press.

Ghezzi A. (2004). Clinical characteristics of multiple sclerosis with early onset. Journal Neurological Science, 25, 336-339. doi: 10.1007/s10072-004-0336-y

Goksel Karatepe, A., Kaya, T., Gunaydn, R., Demirhan, A., Ce, P., \& Gedizlioglu, M. (2011). Quality of Life in Patients with Multiple Sclerosis: The Impact of Depression, Fatigue, and Disability. International Journal Of Rehabilitation Research, 34(4), 290 298.

Harrison, T., Stuifbergen, A., Adachi, E., \& Becker, H. (2004). Marriage, Impairment, and Acceptance in Persons With Multiple Sclerosis. Western Journal of Nursing Research, 26(3), 266-285l. doi:10.1177/0193945903260188

Kralik, D., Koch, T., \& Eastwood, S. (2003). The salience of the body: transition in sexual self-identity for women living with multiple-sclerosis. Journal Of Advanced Nursing, 42(1), 11-20. doi:10.1046/j.13652648.2003.02505.x

Little, R. J. A. (1988). A Test of Missing Completely at Random for Multivariate Data with Missing Values. Journal of the American Statistical Association, 83(404), 1198-1202. doi:10.2307/2290157

Marks, S., \& Millard, R. (1990). Nursing assessment of positive adjustment for individuals 
with multiple sclerosis. Rehabilitation Nursing, 15(3), 147-151. doi:10.1002/j.2048 7940.1990.tb01458.x

Matthews, W.B., Acheson, E.D., Batchelor, J.R., \& Weller, R.O. (1985). McAlpine’s multiple sclerosis. New York: Churchill Livingstone.

McCabe, M. P. (2002). Relationship functioning and sexuality among people with multiple sclerosis. Journal of Sex Research, 39, 302- 309. doi:10.1080/00224490209552154

McCabe, M. P. (2004). Exacerbation of Symptoms Among People With Multiple Sclerosis: Impact on Sexuality and Relationships Over Time. Archives of Sexual Behavior, 33(6), 593-601. doi:10.1023/b:aseb.0000044743.41613.fc

McCabe, M. P. (2005). Mood and self-esteem of persons with multiple sclerosis following an exacerbation. Journal of Psychosomatic Research, 59, 161-166. doi:10.1016/j.jpsychores.2005.04.010

McCabe, M. P., McDonald, E., Deeks, A. A., Vowels, L. M., \& Cobain, M. J. (1996). The Impact of Multiple Sclerosis on Sexuality and Relationships. The Journal of Sex Research, 33 (3), 241-248. doi:10.1080/00224499609551840

McPheters, J. K., Sandberg, J. G. (2010). The Relationship Among Couple Relationship Quality, Physical Functioning, and Depression in Multiple Sclerosis Patients and Partners. Families, Systems, \& Health, 28, 48-68. doi:10.1037/a0018818

Mohr, D. C., Dick, L. P., Russo, D., Pinn, J., Boudewyn, A. C., Likosky, W., \& Goodkin, D. E. (1999). The psychosocial impact of multiple sclerosis: Exploring the patient's 
perspective. Health Psychology, 18, 376-382.

Nosek, M. A., Howland, C. A., Rintala, D. H., Young, M. E., Chanpong, G. F. (2001). National study of women with physical disabilities: Final report. Sexuality and disability, 19(1), 5-39.

Nosek, M. A., Hughes, R. B., Swendlunda, N., Taylora, H. B., Swank, P. (2003). Self-esteem and women with disabilities. Social Science \& Medicine, 56, 1737-1747. doi:10.1016/s0277-9536(02)00169-7

Pakenham, K.I. (2007). Making sense of multiple sclerosis. Rehabilitation Psychology, 52, 380-389. doi:10.1037/0090-5550.52.4.380

Pakenham, K. I., \& Fleming, M. (2011). Relations between acceptance of multiple sclerosis and positive and negative adjustment. Psychology and Health, 26, 1292-1309. doi:10.1080/08870446.2010.517838

Pakenham, K. I., \& Samios, C. (2013). Couples coping with multiple sclerosis: a dyadic perspective on the roles of mindfulness and acceptance. Journal of Behavioural Medicine 36, 389-400. doi:10.1007/s10865012-9434-0

Pfleger, C. H., Flachs, E. M., \& Koch-Henriksen, N. (2010). Social consequences of multiple sclerosis Part 2. Divorce and separation: a historical perspective cohort study. Multiple Sclerosis (13524585), 16(7), 878-882. doi:10.1177/1352458510370978

Prager, K. J. (1995). The psychology of intimacy. New York: Guillford Press.

Rao, S. M., Huber, S. J., \& Bornstein, R. A. (1992). Emotional changes with multiple 
sclerosis and Parkinson's disease. Journal of Consulting and Clinical Psychology, 60, 369-378. doi: 10.1037/e541962006-006

Saleebey, D. (2009). The strengths perspective in social work practice. Boston : Allyn \& Bacon.

Spanier, G. B. (1976). Measuring Dyadic Adjustment: New Scales for Assessing the Quality of Marriage and Similar Dyads. Journal of Marriage and the Family, 38(1), 15-28. doi:10.2307/350547

Stuifbergen, A., Becker, H., Blozis, S., Beal, C., \& Park, I. (2008). Conceptualization and development of the acceptance of Chronic Health Conditions Scale. Issues In Mental Health Nursing, 29(2), 101-114. doi:10.1080/01612840701792548

Tabachnick, B. G., \& Fidell, L. S. (2007). Using multivariate statistics (5 ${ }^{\text {th }}$ ed.). Boston: Pearson/Allyn \& Bacon, c2007.

Tsivgoulis, G. D. (2007). Associations of the Expanded Disability Status Scale with anxiety and depression in multiple sclerosis outpatients. Acta Neurologica Scandinavica, 115(1), 67-72.

Ybema, J. F., Kuijer, R. G., Hagedoorn, M. T., \& Buunk, B. P. (2002). Caregiver burnout among intimate partners of patients with a severe illness: An equity perspective. Personal Relationships, 9, 73-88. doi:10.1111/1475-6811.00005 


\section{Appendix 1}

\section{Quality of Dyadic Relationships Scale 36}

Most persons have disagreements in their relationships. Please indicate below the approximate extent of agreement or disagreement between you and your partner for each item on the following list:

\begin{tabular}{|c|c|c|c|c|c|}
\hline $\begin{array}{l}\text { Always } \\
\text { agree }\end{array}$ & $\begin{array}{l}\text { Almost } \\
\text { always } \\
\text { agree }\end{array}$ & $\begin{array}{l}\text { Occa- } \\
\text { sionally } \\
\text { disagree }\end{array}$ & $\begin{array}{l}\text { Frequently } \\
\text { disagree }\end{array}$ & $\begin{array}{l}\text { Almost } \\
\text { always } \\
\text { disagree }\end{array}$ & $\begin{array}{l}\text { Always } \\
\text { disagree }\end{array}$ \\
\hline
\end{tabular}

1. Handling

family

finances

2. Company

with friends

3. Appropriate

behavior in other

persons' company

4. Values and

religious matters

5. Ways of dealing

with parents,

in-laws and other

relatives

6. Aims, goals, and things

believed important

7. Amount of time spent together

8. Making major decisions

9. Household tasks

10. Leisure time activities and recreation

11. Decisions about career and personal development 
Appendix A (continued)

How often do you think the following situations occur between you? (Mark $\mathrm{x}$ in relevant square)

$\begin{array}{llllll}\text { Never } & \begin{array}{l}\text { Less than } \\ \text { once a }\end{array} & \begin{array}{l}\text { Once or } \\ \text { twice a } \\ \text { month }\end{array} & \begin{array}{l}\text { Once or } \\ \text { twice a } \\ \text { month }\end{array} & \begin{array}{l}\text { Once a } \\ \text { week }\end{array} & \begin{array}{l}\text { More } \\ \text { often }\end{array}\end{array}$

12. Have a stimulating exchange of ideas

13. Laugh together

14. Calmly discuss something

15. Work together on a project

(Mark $\mathrm{x}$ in relevant square)

\begin{tabular}{|c|c|}
\hline Never & $\begin{array}{l}\text { Almost } \\
\text { never }\end{array}$ \\
\hline
\end{tabular}

16. Have often have you discussed or considered divorce/ separation?

17. In general, how often do you think that things between you and your partner are going well?

18. Do you confide in your partner?

19. How often do you think your partner takes his/her responsibility?

20. How often do you and your partner quarrel?

21. How often do you and your mate get on each other's nerves? 
Appendix 1 (continued)

(Mark $\mathrm{x}$ in relevant square)

$\begin{array}{lllll}\text { Never } & \begin{array}{l}\text { Almost } \\ \text { never }\end{array} & \begin{array}{l}\text { Occa- } \\ \text { sionally }\end{array} & \text { Often } & \begin{array}{l}\text { Almost } \\ \text { always }\end{array}\end{array} \quad$ Always

22.How often do you listen

to the expressed wishes

of your partner?

23. How often do you

misunderstand each

other?

24. How often is it a problem in your relationship that you or your partner do not show love and appreciation?

25. How often do you experience that your partner could give you support and comfort if needed?

(Mark $\mathrm{x}$ in relevant square)

$\begin{array}{llllll}\text { Never } & \begin{array}{l}\text { Less than } \\ \text { once a } \\ \text { month }\end{array} & \begin{array}{l}\text { Once or } \\ \text { twice a } \\ \text { month }\end{array} & \begin{array}{l}\text { Once or } \\ \text { twice a } \\ \text { week }\end{array} & \begin{array}{l}\text { Once a } \\ \text { day }\end{array} & \begin{array}{l}\text { More } \\ \text { often }\end{array} \\ & & & & \end{array}$

26. How often do you hug your partner now?

27. How often do you kiss your partner?

28. How often do you wish to hug and cuddle your partner? 
Appendix 1 (continued)

$\begin{array}{llllll}\text { Never } & \begin{array}{l}\text { Less than } \\ \text { once a } \\ \text { month }\end{array} & \begin{array}{l}\text { Once or } \\ \text { twice a } \\ \text { month }\end{array} & \begin{array}{l}\text { Once or } \\ \text { twice a } \\ \text { week }\end{array} & \begin{array}{l}\text { Once a } \\ \text { day }\end{array} & \begin{array}{l}\text { More } \\ \text { often }\end{array} \\ & & & \end{array}$

29. How often the last

4 weeks have you and

your partner been

hugging and cuddling?

\begin{tabular}{|c|c|c|c|c|c|c|}
\hline & Never & $\begin{array}{l}\text { Almost } \\
\text { never }\end{array}$ & $\begin{array}{l}\text { Occa- } \\
\text { sionally }\end{array}$ & Often & $\begin{array}{l}\text { Almost } \\
\text { always }\end{array}$ & Always \\
\hline \multirow[t]{2}{*}{$\begin{array}{l}\text { 30.How often does this } \\
\text { (question 29) approve } \\
\text { to your wishes? }\end{array}$} & $\square$ & $\square$ & $\square$ & $\square$ & $\square$ & $\square$ \\
\hline & Never & $\begin{array}{l}\text { Less than } \\
\text { once a } \\
\text { month }\end{array}$ & $\begin{array}{l}\text { Once or } \\
\text { twice a } \\
\text { month }\end{array}$ & $\begin{array}{l}\text { Once or } \\
\text { twice a } \\
\text { week }\end{array}$ & $\begin{array}{l}\text { Once a } \\
\text { day }\end{array}$ & $\begin{array}{l}\text { More } \\
\text { often }\end{array}$ \\
\hline $\begin{array}{l}\text { 31. How often do you feel } \\
\text { sexual desire? }\end{array}$ & $\square$ & $\square$ & $\square$ & $\square$ & $\square$ & $\square$ \\
\hline $\begin{array}{l}\text { 32. How often is it a proble } \\
\text { that one of you is } \\
\text { too tired for sex? }\end{array}$ & $\square$ & $\square$ & $\square$ & $\square$ & $\square$ & $\square$ \\
\hline \multirow[t]{2}{*}{$\begin{array}{l}\text { 33. How often during the } \\
\text { last } 4 \text { weeks have you } \\
\text { had sex? }\end{array}$} & $\square$ & $\square$ & $\square$ & $\square$ & $\square$ & $\square$ \\
\hline & Never & $\begin{array}{l}\text { Almost } \\
\text { never }\end{array}$ & $\begin{array}{l}\text { Occa- } \\
\text { sionally }\end{array}$ & Often & $\begin{array}{l}\text { Almost } \\
\text { always }\end{array}$ & Alway \\
\hline $\begin{array}{l}\text { 34. How often does this } \\
\text { (question 33) approve } \\
\text { to your wishes? }\end{array}$ & $\square$ & $\square$ & $\square$ & $\square$ & $\square$ & $\square$ \\
\hline
\end{tabular}

35. How often do you think your partner pays attention to your sexual needs? 


\section{Appendix 1 (continued)}

36. Which of the following statements best describes how you feel about the future of your relationship?

I want desperately for my relationship to succeed, and would go to almost any length to see that it does.

I want very much for my relationship to succeed, and will do all I can to see that it does.

I want very much for my relationship to succeed, and will do my fair share to see that it does.

It would be nice if my relationship succeeded, but I can't do much more than I am doing now to keep the relationship going.

It would be nice if it succeeded, but I refuse to do any more than I am doing now to keep the relationship going.

$\square$ My relationship can never succeed, and there is no more that I can do to keep the relationship going. 
Appendix 2

Tennessee Self-Concept Scale $2^{\text {nd }}$ Edition

1= Always False

2= Mostly False

$3=$ Partly False and Partly True

4= Mostly True

$5=$ Always True

*= Reverse score

\begin{tabular}{|c|c|c|c|c|c|}
\hline 1. I am an attractive person & 1 & 2 & 3 & 4 & 5 \\
\hline 2. I am an honest person & 1 & 2 & 3 & 4 & 5 \\
\hline 3. I am a member of a happy family & 1 & 2 & 3 & 4 & 5 \\
\hline 4. I wish I could be more trustworthy* & 1 & 2 & 3 & 4 & 5 \\
\hline 5. I do not feel at ease with other people* & 1 & 2 & 3 & 4 & 5 \\
\hline 6. Math is hard for me* & 1 & 2 & 3 & 4 & 5 \\
\hline 7. I am a friendly person & 1 & 2 & 3 & 4 & 5 \\
\hline 8. I am satisfied with my moral behaviour & 1 & 2 & 3 & 4 & 5 \\
\hline 9. I am not as smart as the people around me* & 1 & 2 & 3 & 4 & 5 \\
\hline 10. I do not act as the way my family thinks I should* & 1 & 2 & 3 & 4 & 5 \\
\hline 11. I am just as nice as I should be & 1 & 2 & 3 & 4 & 5 \\
\hline 12. It is easy for me to learn new things & 1 & 2 & 3 & 4 & 5 \\
\hline 13. I am satisfied with my family relationships & 1 & 2 & 3 & 4 & 5 \\
\hline 14. I am not the person I would like to be* & 1 & 2 & 3 & 4 & 5 \\
\hline 15. I understand my family as well as I should & 1 & 2 & 3 & 4 & 5 \\
\hline 16. I despise myself* & 1 & 2 & 3 & 4 & 5 \\
\hline 17. I don’t feel as well as I should* & 1 & 2 & 3 & 4 & 5 \\
\hline 18. I do well at math & 1 & 2 & 3 & 4 & 5 \\
\hline 19. I am satisfied to be just what I am & 1 & 2 & 3 & 4 & 5 \\
\hline 20. I get along well with other people & 1 & 2 & 3 & 4 & 5 \\
\hline 21. I have a healthy body & 1 & 2 & 3 & 4 & 5 \\
\hline 22. I consider myself a sloppy person* & 1 & 2 & 3 & 4 & 5 \\
\hline 23. I am a decent sort of person & 1 & 2 & 3 & 4 & 5 \\
\hline 24. I try to run away from my problems* & 1 & 2 & 3 & 4 & 5 \\
\hline 25. I am a cheerful person & 1 & 2 & 3 & 4 & 5 \\
\hline 26. I am a nobody* & 1 & 2 & 3 & 4 & 5 \\
\hline $\begin{array}{l}\text { 27. My family would always help me with any kind of } \\
\text { trouble }\end{array}$ & 1 & 2 & 3 & 4 & 5 \\
\hline 28. I get angry sometimes & 1 & 2 & 3 & 4 & 5 \\
\hline 29. I am full of aches and pains* & 1 & 2 & 3 & 4 & 5 \\
\hline 30. I am a sick person* & 1 & 2 & 3 & 4 & 5 \\
\hline 31. I am a morally weak person* & 1 & 2 & 3 & 4 & 5 \\
\hline 32. Other people think I am smart & 1 & 2 & 3 & 4 & 5 \\
\hline 33. I am a hateful person* & 1 & 2 & 3 & 4 & 5 \\
\hline 34. I am losing my mind* & 1 & 2 & 3 & 4 & 5 \\
\hline 35. I am not loved by my family* & 1 & 2 & 3 & 4 & 5 \\
\hline 36. I feel that my family doesn't trust me* & 1 & 2 & 3 & 4 & 5 \\
\hline 37. I am not good at the work I do* & 1 & 2 & 3 & 4 & 5 \\
\hline
\end{tabular}


38. I am mad at the whole world*

$\begin{array}{lllll}1 & 2 & 3 & 4 & 5 \\ 1 & 2 & 3 & 4 & 5 \\ 1 & 2 & 3 & 4 & 5 \\ 1 & 2 & 3 & 4 & 5 \\ 1 & 2 & 3 & 4 & 5\end{array}$

39. I am hard to be friendly with*

40. Once in a while I think of things too bad to talk about

41. Sometimes when I am not feeling well, I am cross

42. I am neither too fat nor too thin

43. I'll never be as smart as other people*

$\begin{array}{lllll}1 & 2 & 3 & 4 & 5 \\ 1 & 2 & 3 & 4 & 5\end{array}$

44. I like to work with numbers

$\begin{array}{lllll}1 & 2 & 3 & 4 & 5 \\ 1 & 2 & 3 & 4 & 5\end{array}$

45. I am as sociable as I want to be

$\begin{array}{lllll}1 & 2 & 3 & 4 & 5\end{array}$

46. I have trouble doing the things that are right $\quad \begin{array}{lllll}1 & 2 & 3 & 4 & 5\end{array}$

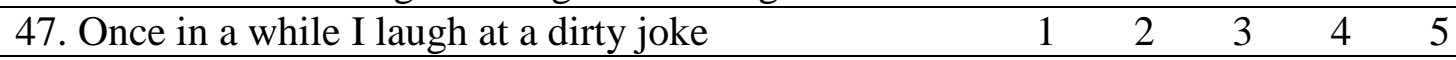

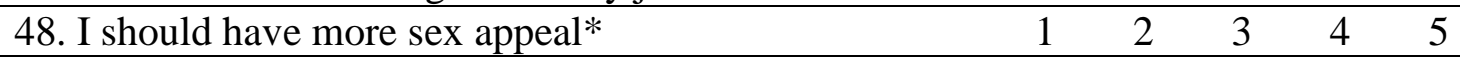

49. I shouldn't tell so many lies*

50. I can't read very well*

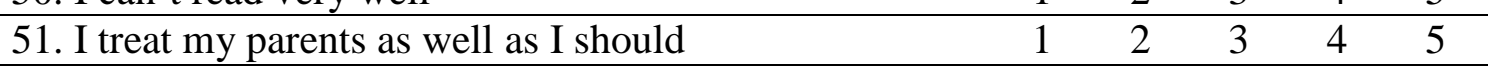

52. I am too sensitive about the things people in my family $\begin{array}{lllllll}1 & 2 & 3 & 4 & 5\end{array}$ say*

53. I should love my family more* $\quad 1 \quad \begin{array}{lllll} & 2 & 3 & 4 & 5\end{array}$

54. I am satisfied with the way I treat other people $\quad \begin{array}{llllll}1 & 2 & 3 & 4 & 5\end{array}$

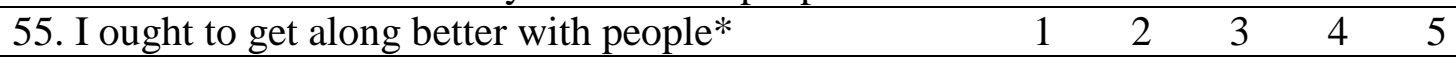

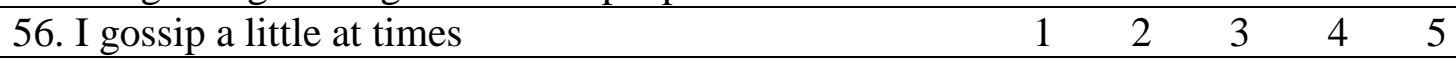

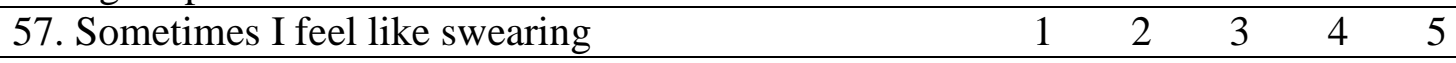

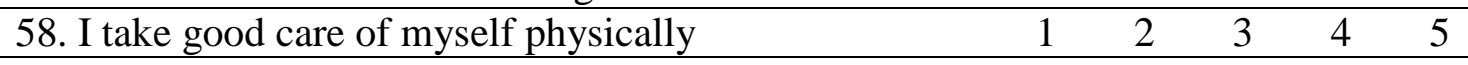

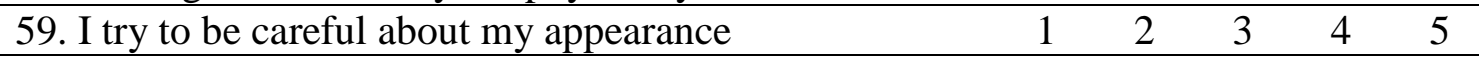

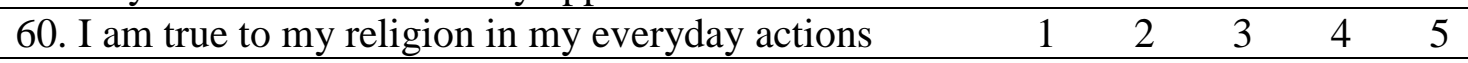

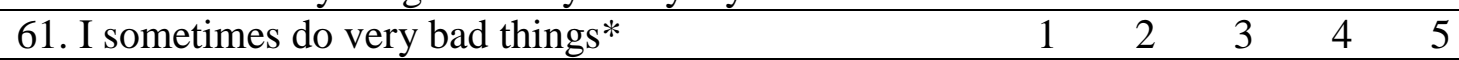

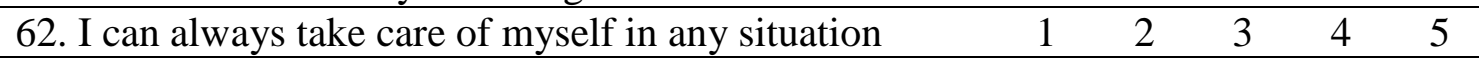

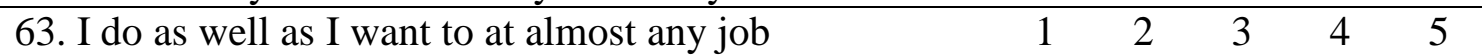

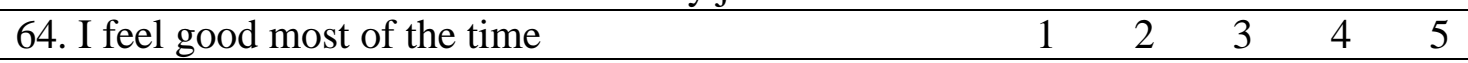

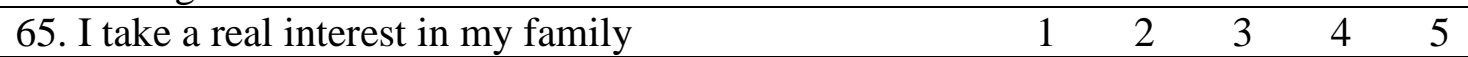

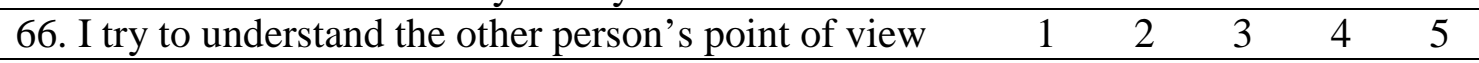

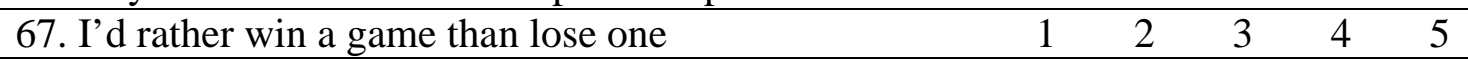

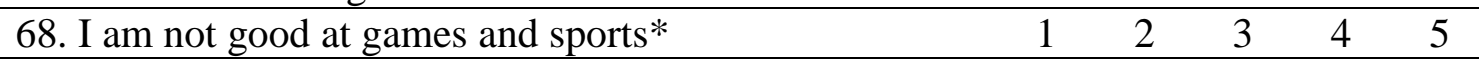

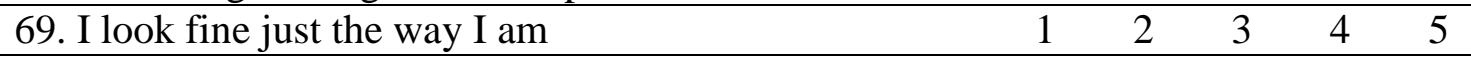

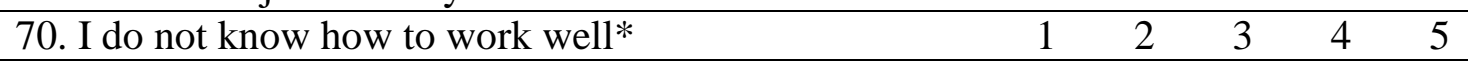

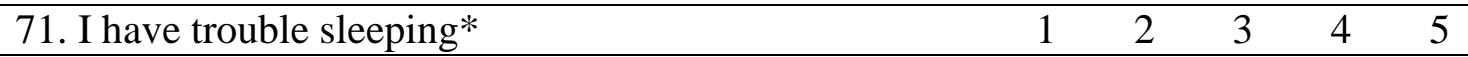

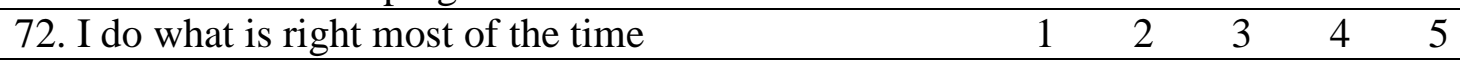

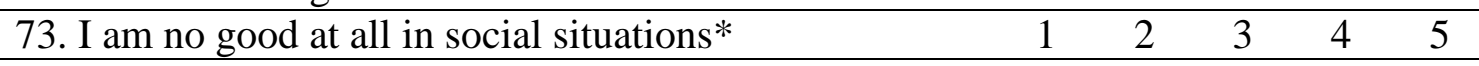

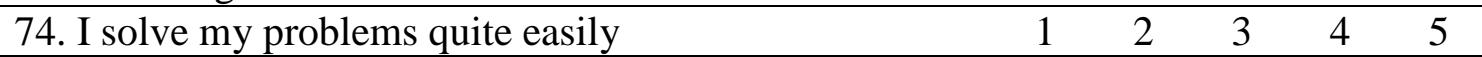

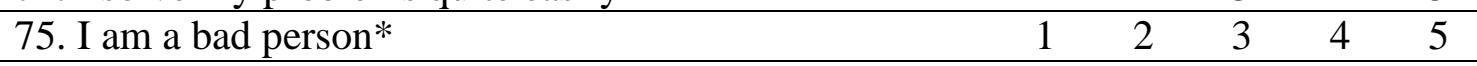

76. I am satisfied with my relationship with God $\quad \begin{array}{lllll}1 & 2 & 3 & 4 & 5\end{array}$

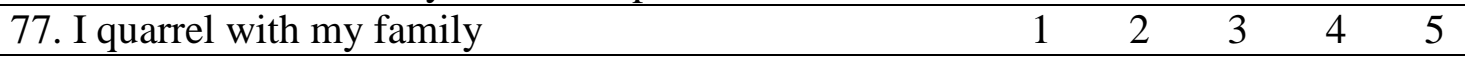

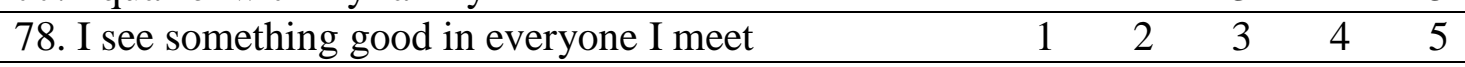

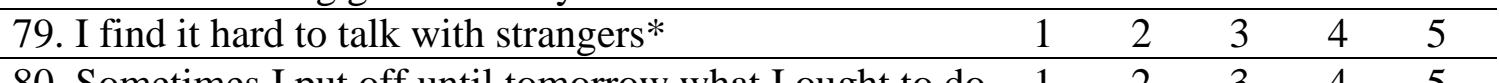

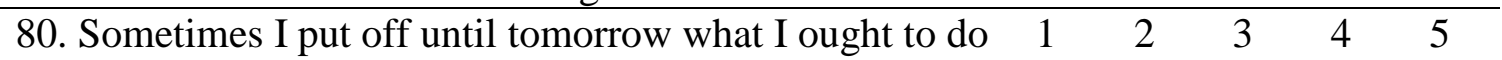
today

\begin{tabular}{llllll} 
81. It's easy for me to understand what I read & 1 & 2 & 3 & 4 & 5 \\
\hline 82. I have a lot of self-control & 1 & 2 & 3 & 4 & 5
\end{tabular}




\section{Appendix 3}

Acceptance of Chronic Health Conditions Scale (MS Adaptation)

I've come to terms with my MS.*

I'd give all my money to get rid of MS.

I think of MS as a curse

I can't conquer MS but I can adapt to it.*

My fondest dream is that I'll awaken without my MS.

Having a disease like MS is just a part of life.*

MS is a focal point in my life.

I spend a lot of time wondering why I have MS.

I think of MS as just part of who I am.*

I think a lot about what my life would be like without MS.

Note. *Reverse score this item. 
Table 1. Descriptive Statistics for intimate relationship quality, illness acceptance and selfconcept.

\begin{tabular}{lcccc}
\hline Scale & $M$ & $S D$ & Range & Possible Score \\
\hline QDR36 & 22.16 & 3.70 & $10.00-27.16$ & $6.00-36.00$ \\
ACHC & 32.10 & 7.42 & $16.00-47.00$ & $10.00-50.00$ \\
TSCS-2 Total & 50.71 & 4.74 & $39.17-62.67$ & $16.40-82.00$ \\
& & & & \\
\hline
\end{tabular}

Note. $n=115$. QDR36= Quality of Dyadic Relationships 36 Scale; ACHC= Acceptance of Chronic Health Conditions Scale, MS adaptation; TSCS-2 Total= Tennessee Self-Concept Scale, $2^{\text {nd }}$ Edition. 
Table 2. Spearman’s correlations between psychological variables of interest.

1.

2.

1. QDR36 total

2. ACHC

$0.28^{* *}$

3. TSCS-Total

$0.45^{* *}$

$0.35^{* *}$

Note. $n=115$. QDR36= Quality of Dyadic Relationships 36 Scale; ACHC= Acceptance of

Chronic Health Conditions Scale, MS adaptation; TSCS-2 Total= Tennessee Self-Concept

Scale, $2^{\text {nd }}$ Edition. ${ }^{* *} p<0.01$ 
Table 3. Multiple Hierarchical Linear Regression Predicting QDR36.

\begin{tabular}{lccc}
\hline & B & (SE) & $\beta$ \\
\hline Step 1 & & & \\
Constant & 23.12 & 0.58 & .04 \\
Illness duration & 0.02 & 0.05 & $-.26^{*}$ \\
EDSS & -0.47 & 0.19 &
\end{tabular}

Step 2

$\begin{array}{lccc}\text { Constant } & 5.79 & 3.46 & \\ \text { Illness duration } & -0.01 & 0.05 & -.02 \\ \text { EDSS } & -0.44 & 0.18 & -.24^{*} \\ \text { ACHC } & 0.02 & 0.05 & .03 \\ \text { TSCS-Total } & 0.06 & 0.01 & .43^{* *}\end{array}$

Note: $R 2=.06$ for Step $1, \Delta R 2=.19$ for Step $2(p<.001) .{ }^{*} p<.05,{ }^{*} p<.01$. QDR36=

Quality of Dyadic Relationships 36 Scale; EDSS= Expanded Disability Status Scale; ACHC= Acceptance of Chronic Health Conditions Scale, MS adaptation; TSCS-2 Total= Tennessee Self-Concept Scale, $2^{\text {nd }}$ Edition. 


\section{University Library}

\section{- $\underset{A C C E S S}{M}$ I R VA A gateway to Melbourne's research publications}

Minerva Access is the Institutional Repository of The University of Melbourne

Author/s:

Wright, TM;Kiropoulos, LA

Title:

Intimate relationship quality, self-concept and illness acceptance in those with multiple sclerosis

Date:

2017-01-01

Citation:

Wright, T. M. \& Kiropoulos, L. A. (2017). Intimate relationship quality, self-concept and illness acceptance in those with multiple sclerosis. PSYCHOLOGY HEALTH \& MEDICINE, 22 (2), pp.212-226. https://doi.org/10.1080/13548506.2016.1238492.

Persistent Link:

http://hdl.handle.net/11343/123418 